\title{
Justice in Tiers: Security Certificate Detention in Canada
}

Mike Larsen, Sophie Harkat and Mohamed Harkat

$\mathrm{T}$ he following is an edited conversation between Mike Larsen, and Sophie and Mohamed (Moe) Harkat, who have been living under the shadow of Canada's security certificate regime since Mohamed's arrest on December 10, 2002. Moe was held in a provincial detention centre from 2002 until April 24, 2006, when he and three other men became the first prisoners to be held in Canada's purpose-built federal prison for security certificate detainees, on the grounds of Millhaven Institution, a maximum security penitentiary. Since June 21, 2006 Moe has been released on severe bail conditions, and he and Sophie have attempted to live their lives beneath an omnipresent microscope of surveillance and control. While the government alleges that he has had ties with terrorist groups and has employed the methods of a "sleeper agent", at no point has Moe been accused of, charged with, tried for, or convicted of a crime.

In July 2008, Sophie travelled to London, UK to attend the Universal Carceral Colloquium at the 12th International Conference on Penal Abolition (ICOPA XII), where she and Mike spoke about security certificates. Sophie's talk "A Long and Painful Road to Freedom and Justice, Or: Once Free, Now a Full-time Jailer" provided the springboard for an ongoing conversation, which in turn formed the basis of this article. On a rainy day in September 2008, Mike, Sophie and Moe were able to sit down at the Harkat's Ottawa home to discuss security certificate detention, secret trials and the bail conditions that have transformed the Harkat's residence into a carceral space. Each section that follows opens with contextualizing comments by Mike, followed by an exchange with Sophie and Moe.

\section{Security Certificates and Two-Tiered Justice}

To begin, it is important to briefly outline what security certificates are and how they operate. At first glance, one could be forgiven for assuming that certificates fall under the auspices of the Canadian criminal justice system - after all, they involve allegations from the state, arrest, imprisonment and the courts. But the devil is in the details and upon closer examination, one finds that security certificates operate as part of a parallel legal regime, not criminal but administrative in nature. They emerge from section 77 of the Orwellian-titled Immigration and Refugee Protection Act (IRPA), which allows the Ministers of Public Safety and Citizenship and Immigration 
to sign a certificate deeming a non-citizen to be threat to the security of Canada, and ordering that person to be detained pending deportation. If a judge of the Federal Court determines the certificate to be objectively reasonable - a standard of proof significantly lower than that used in criminal law - it becomes "conclusive proof that the person named in it is inadmissible and is a removal order that is in force without it being necessary to hold or continue an examination or admissibility hearing" (IRPA, s.80). The decision cannot be appealed. Certificates are based on intelligence collected by the Canadian Security Intelligence Service (CSIS) and this information is generally classified as sensitive and potentially injurious to national security. Accordingly, individuals subject to security certificates - and their legal counsel - are not allowed to view the full dossiers of evidence against them, but are instead given summaries. For this reason and for their generally clandestine nature, security certificate cases have come to be known as Canada's "Secret Trials". This term captures the essence of the mechanism, but it is important to bear in mind that with certificates, there is in fact no formal trial at all.

Certificates operate according to the same precautionary logic that has underpinned many of the disastrous policies of the so-called "war on terror" (see Ericson, 2007). One is not imprisoned pending deportation on a security certificate because of accusations about specific acts that have allegedly been committed; rather, one is imprisoned because they are deemed to represent a future threat, and because, as Razack (2008) notes, they fit a particular profile. In the post 11 September 2001 context, the potential threat in question is terrorism and the profile of interest to authorities is that of the male, Muslim, Arab, non-citizen. The five men currently subject to security certificates - known as the "Secret Trial Five" - fit this profile. By virtue of this profile and allegations about their past associations, CSIS has declared them to be the potential authors of future calamities.

While the stated purpose of a security certificate is to "remove" the individual in question from Canada, the government has not been able to deport the "Secret Trial Five", due in large part to a series of ongoing legal challenges (and associated activist campaigns) that have exposed the unconstitutional nature of the mechanism. The efforts have resulted in numerous amendments to law and policy, including a 2006 ruling by the Supreme Court of Canada that found the process to be unconstitutional. Additionally, each of the Five has argued that deportation would put them at risk of torture in their country of origin (Algeria, Egypt, Morocco, and Syria), violating Article 3 of the UN Convention Against Torture (UNCAT), which prohibits "refoulement". The net result of this complex 
and exceptional situation is that the effect of the current certificates has morphed from removal to long-term, indefinite detention, administered by the Canada Border Services Agency (CBSA).

Mike: All of this is possible only because certificates operate through immigration law and in relation to non-citizens only. ${ }^{1}$ Their targets are not recognized as members of the Canadian political community. Many have called certificates a clear example of two-tiered justice. Is this the case?

Sophie: We do have a two-tiered system in Canada. Security certificates target only non-status individuals, refugees and immigrants, and they allow for indefinite detention, in most cases for years - without access to the evidence. Hassan Almrei has been in detention since 2001 and has spent half that time in solitary confinement. In my husband's case, he spent 43 months in detention and his first year was in solitary. What we have to remember is that the individuals in question, no matter their status, are human beings. We have a criminal justice system in place, but instead of using it, the government has chosen to adopt a system that leaves noncitizens without rights, in the dark, and at risk of deportation and torture or death.

Mike: When [then Public Safety Minister] Stockwell Day addressed Parliament during the debate over the latest amendment to certificate law, Bill C-3, he said "I would encourage all colleagues to set aside partisanship to realize that the security certificates have been proven not to threaten the individual rights and freedoms of Canadians. As a matter of fact, the security certificate cannot even be applied against a Canadian citizen. It can only be used on foreign nationals or those who are not Canadian citizens" (Day, 2008). Have you found it difficult to mobilize Canadians in opposition to certificates, given their application to non-citizens only?

Sophie: Even though certificates apply directly to non-citizens, they affect all of us - and they are applied in our names. They affect the wives, kids, families and friends of the men, many of whom are Canadians. At first, I found it hard to convince Canadians that this law was unfair, because of the taboos around September 11 and terrorism. Not many wanted to associate themselves with us or support a cause like this. Many had the mentality that, although the evidence was secret and they knew this was wrong - in their hearts, minds and according to the Charter of Rights and Freedoms - it was still necessary. Many kept saying "well, there must be something to it if they arrested them". I have always turned that question 
back at such individuals and asked them if they would approve of a law that might put them in a similar situation of legal limbo - would they accept such a process if it affected Canadians? Everyone says "no". So I argue that all human beings deserve a chance to defend themselves openly and fairly in a court of law. Since the beginning, we have had supporters who know that this law is wrong and who have been demanding justice. More and more, people agree that there is no security without human rights and vice versa.

Moe: Remember, I was arrested in the period right after September 11. At that time, governments felt that they could arrest anyone who they thought was suspicious. The Canadian government felt pressure and wanted to show that they were "doing something" about terrorism. I think that I made an easy target. In a way, I think they made the case to fit the story: with me, they had a high-profile case about a Muslim refugee who had come to the country on a false passport. Maybe they thought it would be an open and shut case.

They were not expecting us to resist. They wanted me to just accept it and go, and they definitely did not want me to question the case and to keep digging. When you dig, you find out, for example, that they cannot guarantee that evidence in my case did not come from torture.

Sophie: You know what I am afraid of? Twenty years from now, after the truth has come out and Moe is exonerated, we will bump into somebody on the street and he will say "hey, I recognize you. Aren't you the terrorist guy?" I worry that Moe will always remain suspicious to some. We see this with the cases of Arar, Almalki, Abou-Elmaati and Nurredin. ${ }^{2}$ This lingering suspicion has ruined and destroyed lives.

Moe: These cases really frustrate me. They show how governments will never wilfully admit to their mistakes. If you look at the Arar case, the RCMP clearly acted inappropriately. They knew it all along, but they only owned up to it after a full public inquiry. The government ignores the psychological damage that this does to the people who are labelled "suspicious". Just like Arar, I will have to live with these allegations for my whole life and I cannot fight them in court. I have never been formally charged with anything, but there is no presumption of innocence. The secrecy makes it hard for people to follow the case too and this is no accident. It is a tactic. The government makes some vague allegations, mentions a few details and people judge based on that. And people always weigh these cases against the backdrop of September 11, thinking "we 
don't want that to happen again". It is this fear, I think, that makes some people willing to overlook the injustice [of security certificates].

\section{Provincial Detention}

Until spring 2006, security certificate detention took place in Canada's provincial jails, under an agreement between the Canada Border Services Agency (CBSA) and the provinces similar to the one that governs "high security immigration detention" more generally. Certificate detainees were held for periods of two to six years in facilities intended for remand custody or short-term sentences. Resistance to the conditions of detention and to the security certificate regime more generally, led to protracted hunger strikes by the detainees, along with an expanded public campaign to stop secret trials in Canada.

Mike: Moe, your detention has gone through several phases, each with its own uncertainties. At first, you were held at a provincial jail, the OttawaCarleton Detention Centre (OCDC). Describe this experience.

Moe: I was arrested on Human Rights Day and I spent about a year in solitary confinement. For a while, I was treated as though I did not have any rights at all. I was in shackles, cuffs, feet and waist, and I was not allowed to shave for 45 days. I was made to feel like an animal. It was three months before I had Halal food and only after I refused to eat other food. They did not permit me to have a Qur'an for several months. Later, I was transferred to supermax, which was in lockdown, but I was still able to have some contact with other prisoners. When I left solitary, when I could hear other people through the doors, I felt as though I was coming to life again. But I still could not sleep. At this time, I knew nothing about my case. It was all uncertain and I did not speak English very well. They kept telling me "we are holding you until we can send you back to Algeria. We are going to deport you" and this was terrifying. It was like waiting to be walked to my own execution - which is what would happen if I was to be deported with these allegations hanging over my head.

Over time, it became clear that they [the prison authorities] were almost as uncertain about my situation as I was. I was in provincial detention for a long time and they had no policy for that. It was supposed to be a short period, but it dragged on for years, because I refused to quietly leave the country. The other guys, the other prisoners, they knew how long they were there. They knew their cases, for the most part and they knew their rights. I was surprised at first at how much they sympathized with me, 
but, looking back, it makes sense that other prisoners would understand what it is like to have someone throw you in jail and then throw away the key. They could understand that we were all human beings and that we all deserve justice.

Sophie: For myself, I was very nervous when I first went to see Moe. I remember my heart beating so fast that I was vibrating on my chair. I did not see Moe for the first few days and did not know if he was going to be deported in the meantime. I had never expected to visit someone I love in jail - especially someone so close to me. I was hoping to never end up there and unfortunately I did. I had a different opinion back then of the prison system then I do now. Moe was in segregation the first year I visited him. He was in a small glass box at the end of the general population. He was wearing a bright orange suit just like in Guantanamo. Now, he refuses to wear orange! My family was devastated having to visit him there and not being able to hug him, and my niece who was three at the time did not understand why so many "police officers" would watch uncle Moe. I was kept away from Moe for days at a time [sometimes weeks] without having any news from him. Just like Moe, I was unable to sleep, for the first two years.

The conditions were awful. Most of the phones would not work and it felt like 100 degrees in there all the time. There was no fresh air to breathe. I could see Moe through a glass only twice a week for twenty minutes. I would often wait for four hours to see him in a waiting room that was really freezing in the winter and boiling hot in the summer. I remember having to ask permission in front of all the visitors to use the washroom that was behind the security guard and the sound of those big heavy metal doors closing behind each person who visited. It was the loudest vibrating noise ever. I heard those doors so many times - too many times. I will remember that sound always.

I feared for Moe's life every day, especially when he was later moved to the maximum security section with the toughest criminals, those who made the news! They ended up protecting him, though. The other prisoners supported my husband and were good to him. They understood that someone without any charge did not belong in jail and that he deserved a fair trial. I always knew that after a bad decision in court, they would be there for him. I now have a profound respect for prisoners. Some end up waiting years for a trial or even a court date or end up getting a sentence which turns out being shorter then the time they were held in remand. Often, I would overhear discussions between prisoners and their families, and the sadness and inhumanity of their circumstances brought me to tears 
on numerous occasions. I was shocked to hear prisoners complaining about being hungry or about being cramped in a double-bunked cell or sleeping on dirty floor infested with bugs.

Moe was cut off from the outside world. He did not see the sky for the first six months and he had no access to newspapers, TV or radio, so he could not appreciate how important his case was becoming on the outside. The length of time he spent in provincial detention was extraordinary. Most prisoners would spend two years less a day in provincial detention, if they were serving a sentence, or they would be held awaiting a sentence or a transfer.

It has been more than two years since Moe was released under house arrest and I became a jailer to my own husband. Talking about this reminds me of how horrible those 43 long months were. It is like I blocked that time out of my memory and I never want to relive it. I do not wish that sort of experience on anyone.

\section{Guantanamo North}

Controversy over the use of provincial facilities for long-term security certificate detention grew throughout 2005 and early 2006. On April 19, 2006 a Memorandum of Understanding was signed between the Canada Border Services Agency (CBSA) and the Correctional Service of Canada (CSC) concerning the management and operation of a brand new facility called the Kingston Immigration Holding Centre (KIHC). ${ }^{3}$ Located on the grounds of Millhaven Institution in Bath, Ontario, the six-cell KIHC exists exclusively for the detention of individuals subject to security certificates or, in government acronym-speak, ISSCs. ${ }^{4}$ This is a prison within a prison, with its own perimeter and security gate, its own specially cross-trained workforce of "multi-function detention officers", and its own set of rules, guidelines, President's Directives and Standing Orders. More than this, though, it is a deeply-problematic hybrid, where CSC has been contracted as a detention "service provider" by the CBSA, the "detention authority". This contractual arrangement allows CSC to effectively set aside the entire "correctional" component of their mandate and to circumvent the basic principles of the Corrections and Conditional Release Act (CCRA) (see Larsen and Piché, 2007).

The exceptional nature of security certificate detention is at odds with everything that CSC claims to stand for. Normally mandated with the supervision of prisoners serving federal sentences longer than two years and with the development and administration of "correctional" programs - deeply flawed processes in their own right - CSC's role at 
$\mathrm{KIHC}$ is reduced to that of long-term jailer. The prisoners held at KIHC are detained without charge or trial, much less a fixed sentence, and the technically transitory but effectively indefinite nature of their detention - which is officially "pending removal" - means that they have no access to the programs or meager educational opportunities available to federal prisoners serving sentences. KIHC is the concrete manifestation of the make-it-up-as-you-go nature of the entire security certificate process - a permanent space of legal exception (see Agamben, 2005; Nyers, 2006), simultaneously outside the criminal justice system and embedded in its institutional structure.

In the grand scheme of things, KIHC is a small facility. For a short time, it held four security certificate detainees, but since late 2006 its sole occupant has been Hassan Almrei, who has been in de facto solitary confinement by virtue of his being the only detainee unable to secure bail. But small and exceptional as it is, the emergence of KIHC is a major development in Canadian federal imprisonment (Larsen and Piché, 2007). It represents the unrestrained sovereign power of the state and reveals the underlying essence of the prison, which stripped of the trappings of "correctional" rhetoric, is about the coercive deprivation of liberty. It should come as no surprise that KIHC is known to many of its opponents as "Guantanamo North".

Mike: The opening of KIHC came as a surprise to many of us following the cases. While there were rumblings about a shift from provincial to federal detention arrangements, there had been no public discussions, much less a detailed plan. How did the transfer unfold?

Moe: They came one day and told me that I had a visitor. They took me to the visitors' area with my shoes and a coverall. The RCMP took me to the airport, put me on a plane and flew me to Kingston.

Sophie: I call it your kidnapping. It was a "visit" at a time that normal visits didn't occur. I only found out about the transfer when one of the other prisoners at the provincial jail panicked and called collect to tell me that Moe had been taken away. Luckily, I was home to receive the call, so I was able to alert the media and the other families. I remember thinking "what if they just deport him instead?" At the time, the guys [the security certificate detainees] were hunger striking. The conditions at the jails were attracting a lot of attention, which prompted the government to do the transfer quietly and in secret. There was no announcement and no media on hand to film them leaving or arriving. 
Mike: How did KIHC compare to provincial detention?

Moe: Before the transfer, when they told us about the new prison, and when we discussed it with our lawyers, the government said "it will be much better. You will be able to read, study, work out, exercise". They said "this is what you are going to get". But it was all just ink on paper. We could not study, could not work and had no trailer visits. I would say they gave us 10 percent of what we expected. And the staff - the guards and managers - they were from different agencies. It was confusing, and often the CBSA and federal prison (CSC) people did not know how the law was applied. We had no interactions, no contact at all, with other prisoners. Sometimes, when we were outside, on the concrete, we could look out, past the two barbed wire fences and see other prisoners in the distance, working - mowing the grass or cleaning the yard. But we were different, and we knew it. ${ }^{5}$

Sophie: I think all Canadians should be appalled that Canada has its own "Guantanamo North" in the Kingston area. It tends to shock many when they find out about it. Right now, although there is only one "presumed terrorist" being held there, it is costing the taxpayers millions of dollars per year. ${ }^{6} \mathrm{KIHC}$ is located on a large field outside one of the largest penitentiaries in the country and is surrounded by three sets of barbed wire. It is difficult to get to. There is no public transit and a cab to the prison costs a fortune. The KIHC facility is a simple portable unit like you see in many school yards. When it was first built, it was freezing cold in the winter and boiling hot in the summer. The building shook when the men walked around inside. They had a fenced-in yard with a concrete floor.

Kingston is halfway between Toronto and Ottawa, but still hours away from both. This made visits difficult and expensive for family, and even for the counsel representing the men. It was also very difficult to arrange a visit and all visitors had to go through a pre-screening process, including a lengthy criminal background check, on top of the metal detectors and drug scanners at the prison. On my first visit, I tested positive for cocaine, and a very loud siren and the alarm system started. I have never used drugs in my life. The water bottle I was carrying had traces of it, apparently. This was just another humiliation for me, but by now I was used to the degrading experience of being a spouse visiting her husband in prison.

We quickly discovered that none of the provincial detention centre rules applied at KIHC, which is an immigration facility, and there was a difficult period of adjustment. At first, there were many problems around access to 
medical care. Mohammad Mahjoub, for example, barely got any care for the Hepatitis he contracted in Toronto jail. I was lucky that my husband's time there was cut short when he was later released under another form of incarceration - full house arrest. Every day, I think of Hassan Almrei, the last remaining detainee and how lonely he must be. There is no contact with the outside world unless you are pre-approved by CBSA and the visit is pre-approved weeks in advance, and there is no contact with other prisoners whatsoever. The men were kept away from it all and in the dark - a reflection of the security certificate process in general.

Mike: Many people have argued that KIHC, despite its faults, is preferable to the provincial system. Despite this, you have both consistently called for the abolition of KIHC, as have I. How do you respond to the argument that KIHC, exceptional and problematic as it is, represents a 'lesser evil'. Where should security certificate detainees be held?

Sophie: Where do you put them? That is easy. You put them where people with no charge or conviction belong: at home, with their families. This has been our position from the start. Either charge them or release them. One thing I have learned is that you cannot tinker with injustice. You cannot change one detail here, one detail there and hope to fix a fundamentally flawed system. If it is unjust, you need to attack it head-on and to abolish it.

\section{Prisoners at Home}

Four of the "Secret Trial Five" have now been released on bail, placed under house arrest with incredibly strict conditions. The decisions to release the detainees were subject to extensive contestation from the government, which argues that the men continue to represent a threat to the security of Canada. Despite this, the Federal Court - which has historically been thoroughly complicit in the perpetuation of the security certificate regime - determined that continuing to hold some of the men in custody was unreasonable. But, as the released detainees - Charkaoui, Harkat, Jaballah and Mahjoub - have convincingly argued, the fact that they are no longer in prison does not mean that they are no longer prisoners, much less that they are free. Rather, the disciplinary apparatus

of the prison, including its guards, cameras, and rules, have been extended to the homes and communities of the detainees.

Mike: Sophie, you mentioned previously that the men should be at home, 
rather than in detention. But there is a difference between being at home under conditions and being free. Do the two of you consider your current circumstances to be another form of imprisonment?

Moe: Yes, absolutely. In some ways, being at home is much more strict and controlled. It is certainly more stressful, which surprised me. In jail, I did not have to tell the guard when I had to use the bathroom. Now, because the bail conditions require Sophie to be with me at all times, if I need to use a men's room while on a scheduled outing, we need to call CBSA for approval. I believe that the government wants to make things as intolerable as possible, so that we become desperate and give up. Their approach seems to be "If you don't like it, just go".?

Sophie: Security certificate bail is definitely another form of imprisonment. Moe and I are prisoners in our own home and when we leave on approved outings it is only under a bubble of surveillance. These bail conditions are unprecedented in Canadian history and they have forced me to take on the role of full-time jailer to my own husband. Everyone in our family is paying the price.

Just to give you an idea of how the bail conditions act to imprison and control us: they include the requirement that Moe wear a GPS tracking bracelet 24/7 and a heavy monitor on his belt during outings. He requires constant supervision by myself, my mother or another surety who has been approved by the Federal Court, and he can never be left alone outside or inside our home. The sureties had to collectively put up approximately $\$ 100,000$ as a guarantee.

There are surveillance cameras at the entrance to our house and inside. Our telephone is tapped and our mail is intercepted. Moe is not allowed to go anywhere near my computer, which must be kept under lock in my office. This extends to all electronics, including cell phones, laptops and anything with an Internet connection.

We are allowed three weekly outings of four hours in length and we must be back before the deadline. Moe is not allowed to have any travel documents and he has strict boundaries within the City of Ottawa. He is unable to enter certain government buildings or to attend certain events, like the Lebanese Festival - though he could attend the Greek Festival. He is not allowed to ride boats, nor can he go near a bus station, train station, rental company or airport.

All locations we visit are pre-approved by CBSA, as are all meetings and all visitors. He has to call CBSA before and after each outing, and we are followed by CBSA officers with bulletproof vests and guns. These 
officers have the right to enter our home at any time. Every visitor must go through security clearance, just as though they were visiting Moe at KIHC. Many have not been cleared because of previous criminal records or because of their involvement in activism. Even my grandmother and six year old niece had to be pre-approved. Also, Moe is not allowed to speak Arabic in public - only on the telephone with his family.

Additionally, Moe can only speak to pre-approved media. This has caused lots problems with the press about freedom of speech and has made our work with the media very difficult, and at times impossible. Because of this, the campaign has taken a major hit because I am stuck at home with Moe and cannot just leave our home to do interviews in studio like before.

These are just some of the conditions. I could talk about the others, but the point I want to emphasize is that these conditions have come to define and control every aspect of our lives. We live in fear of accidentally breaching a bail condition, which would result in Moe being arrested and detained again. This has happened in the past. This level of surveillance and control is humiliating and degrading, and there is no escaping it. For example, because he cannot be left alone, Moe has attended my physicals and other "women" appointments, where he sits in the corner. We have no privacy, no potential for spontaneity.

Moe: This is the worst part. You [Sophie] are suffering because of me. It is a huge sacrifice. When I was in jail, I did not have this stress. I felt as though I was waiting to be walked to my own execution, but it was just me. Now, I worry about everything. If I breach my conditions, I will go back to prison; my family will lose the surety money; the government will use it as an opportunity to further the security certificate system; and we will lose the trust of the Canadian people. Since I have been out [of KIHC], I have been preoccupied, always thinking "will you make it back home in time for your curfew? What if the car breaks down?" The conditions affect my family and disrupt their lives. In many ways, it has cut them off from the world.

Sophie: It is terrible to hear him say "I'm going to voluntarily go back to jail", which he does sometimes, out of frustration. ${ }^{8}$

\section{Conclusion}

Mike: What I take from our conversation is that there are degrees of imprisonment that apply to security certificate detention. Despite the 
frustration and stress, it seems that house arrest is still preferable to full incarceration. But the distinction between the two is blurry and some elements are common as every form of imprisonment we have talked about - provincial, federal and through intensive bail - is characterized by constant uncertainty. From the initial fear that Moe would be deported directly to Algeria, to the ambiguity of the rules governing KIHC, to the everyday experience of unease associated with 24-hour surveillance. The physical location of the carceral changes, but many of the elements - techniques of control and technologies of surveillance, guards, rules, boundaries and restrictions - remain constant. This, I think, is a perfect illustration of the dangers of the universalization of the carceral, in that it shows how systems of confinement with roots in the prison can, over time, and through contortions of law and policy, extend beyond the walls of the institution, into the community and throughout society. Where do we go from here?

Moe: I have learned that you never quit when you are right. If you are innocent, you fight for it. Some people would take a deal in this situation and compromise even though they knew they were innocent. But this only allows the injustice to continue. Never lose hope. One day, I will have the opportunity to clear my name. The truth will come out. It is a matter of time.

Sophie: Security certificates are inherently unjust. As a Canadian, I feel appalled at the way we are operating a two-tiered system of laws, where these men can be imprisoned on the basis of suspicion alone. But pity and fear will not get us anywhere, so it is important to take action, and to take a stand against injustice. We often talk about the importance of striking a balance between security and liberties. Well, when you have indefinite detention without trial and when you have a system that makes it possible to deport someone to face torture you have failed to strike the right balance. Every individual in this country, citizen or not, should have an equal right to justice. We need to abolish security certificates and to do away with secret trials. 


\section{ENDNOTES}

1 For a more in-depth discussion of Canada's immigration detention system, of which security certificate detention is an exceptional example, see Anna Pratt's (2005) book Securing Borders.

2 Maher Arar, Abdullah Almalki, Ahmad Abou-Elmaati and Muayyed Nurredin are all Canadian citizens who became victims of the US-led program of "extraordinary rendition" in the years following September 11, 2001. They were abducted and sent to Syrian dungeons, where they were detained and tortured at the behest of western officials. After considerable hesitation, the Canadian government launched a Royal Commission of Inquiry (the O'Connor Commission) into the treatment of Maher Arar and an Internal Inquiry (the Iacobucci Inquiry) into the treatment of the other men. Both Inquires examined the complicity of Canadian officials in the mistreatment of the men and pointed out serious deficiencies in official conduct. None of the men were ever charged with a crime. Maher Arar was given a public apology and a compensatory settlement. Despite this and because of the pervasiveness of the "no smoke without fire" mentality that Sophie alludes to in her remarks, some still regard Arar and the others with suspicion, and assume that they must be guilty of something.

3 A copy of the CBSA-CSC Detention MOU was obtained through an Access to Information Act request (no. A-2007-00267) filed with the Correctional Service Canada. The document is a fascinating example of how legal loopholes are created and exploited. It takes only 14 pages to set out the details of a contractual arrangement that completely blurs the boundaries between corrections and immigration detention.

4 It has been possible to obtain, through requests made under the Access to Information Act, (including request A-2007-01287, made to CBSA) many internal government documents relating to security certificates and the administration of the Kingston Immigration Holding Centre. In some documents, certificate detainees are referred to simply as "detainees", while in others, the acronym ISSC, for Individuals Subject To Security Certificates, is adopted. The acronym is part of the internal institutional lexicon and is not seen in remarks made to the public.

5 The KIHC operating guidelines that have been obtained through Access to Information Act requests are very clear on this point. Security certificate detainees are to be separated from other prisoners at all times. For example, General Principle 9 of the CBSA-CSC Detention MOU states that " $[t]$ o the greatest extent possible, there shall be no contact or communication between any detainee and any prisoner of the Millhaven Institution or any other CSC institution or facility". This policy stems in part from article 10 of the International Covenant on Civil and Political Rights (ICCPR) and was discussed long before the creation of KIHC, including in a November 2001 draft document entitled Detention of Individuals Not Serving a Sentence Nor Awaiting Trial: Position of the Correctional Service of Canada, obtained through the Access to Information Act (Request no. PS-SP A-2008-0023).

6 For more on security certificate detention costs, see the May 13, 2008 CBC story "Lone detainee Almrei costs taxpayers \$2M annually at Kingston facility", available 
at http://www.cbc.ca/canada/ottawa/story/2008/05/13/ot-kingston-holding-080513. html.

7 Canadian officials have notoriously referred to security certificate detention as taking place in a "prison with three walls", implying that the detainees are free to go at any time, provided they voluntarily return to their countries of origin, where they fear torture or worse.

8 The thought of voluntarily returning to prison, rather than living with such restrictive bail conditions, has been echoed by other security certificate detainees. In March 2008, Mohammad Zeki Mahjoub requested that he be returned to prison, saying that he could no longer handle the 24-hour surveillance. The request was denied on the grounds that he had not breached his conditions. In a November 24, 2008 Globe and Mail article, reporter Colin Freeze quoted Mr. Mahjoub's wife, Ms. El Fouli, as saying “"“He's feeling his children are getting punished," [...] adding that when her husband tried to go back to prison, he told her that as long as he lived on the outside, "they are not putting me only in jail, they are putting all of you in jail."” The article is available at http://www.justiceforharkat.com/news.php?extend.3047.

\section{REFERENCES}

Agamben, Giorgio (2005) State of Exception, Chicago: University of Chicago Press. Day, Stockwell (2008) House of Commons Debates, Canada - 041 - January 31.

Ericson, Richard (2007) Crime in an Insecure World, Cambridge: Polity.

Larsen, Mike and Justin Piché (2007) "Incarcerating the Inadmissible: KIHC as an Exceptional Moment in Canadian Federal Imprisonment", YCISS Working Paper 45, Toronto: York Centre for International and Security Studies.

Nyers, Peter (2006) Rethinking Refugees: Beyond States of Emergency, New York: Routledge.

Pratt, Anna (2005) Securing Borders: Detention and Deportation in Canada, Vancouver: UBC Press.

Razack, Sherene H. (2008) Casting Out: The Eviction of Muslims from Western Law \& Politics, Toronto: University of Toronto Press.

\section{Legislation and Conventions}

Convention Against Torture and Other Cruel, Inhuman or Degrading Treatment or Punishment, GA Res. 39/6 (1984) - December 10 (entered into force June 26, 1987).

Corrections and Conditional Release Act (CCRA), S.C. 1992, c-20.

Immigration and Refugee Protection Act (IRPA), S.C. 2001, c-27. 


\begin{abstract}
About the Authors
Mike Larsen is a $\mathrm{PhD}$ candidate in Sociology at York University and a Researcher at the York Centre for International and Security Studies (YCISS). He has recently become a Managing Editor of the Journal of Prisoners on Prisons. His work deals with contemporary policies of indefinite and preventive detention, with a specific focus on Canada's security certificate regime which combines a critical sociology of law with investigative work using Access to Information law. Mike was one of the organizers of the Universal Carceral Colloquium at ICOPA XII. His chapter "Governing Non-Citizens as Security Threats: Canada's Security Certificate Regime" is forthcoming in the YCISS edited volume Violent Interventions.
\end{abstract}

Sophie Harkat, from Ottawa, Canada, became an activist overnight after her husband Mohamed Harkat was arrested under a security certificate on December 10, 2002 (International Human Rights Day). Since Moe's release on bail in June 2006, Sophie has had to juggle the roles of activist and full-time jailer to her own husband. Moe has become her hero, and biggest source of inspiration and motivation. Her simple life has became a nightmare, but along the way she has gained support, love, and respect from many and is now dedicated to standing up to the injustices of her own government, including abolishing security certificates. You can visit the Justice for Mohamed Harkat website at http://www.justiceforharkat. com/news.php .

Mohamed Harkat was born in Algeria and left at an early age in light of the tense political situation and his involvement with the Front Islamique du Salut. He sought employment at a refugee camp in Pakistan and eventually moved to Canada in 1995, and was granted refugee status in 1997. He built a life in Ottawa, working three jobs and married Sophie in early 2001. His peaceful life was shattered when he was arrested on a security certificate. Since then he has spent 43 months in detention, followed by 2.5 years of house arrest. He has maintained his innocence from the start and looks forward to clearing his name, settling down to raise a family, and being able to live without fear. In the meantime, he draws strength from his family, and he is surrounded by dedicated supporters and a wonderful legal team. 